\title{
Antecedents of Strategic Orientations in Romanian SMEs: An Institutional Framing Perspective"
}

Oana Cătălina Iederan, Petru Lucian Curşeu, Patrick A.M. Vermeulen, Jac L. A. Geurts ${ }^{* *}$

Using data from 325 Romanian SMEs, we test the joint effect of perceived opportunities and threats in a situation of macro institutional change on strategic orientations. Our findings show that perceived threats moderate the impact of perceived opportunities on SMEs strategic orientation in such a way that perceived threats increase the positive association between perceived opportunities and the prospector strategic orientation, as well as the negative association between perceived opportunities and the defender strategic orientation. Implications of current findings for the framing perspective in institutional theory are also discussed and directions for future research are drawn.

Auf Basis von 325 rumänsichen KMUs, testen wir die Wirkung der Chancenund Risikeneinschätzung in einer Situation der makroinstitutionellen Veränderung der strategischen Ausrichtung. Unsere Ergebnisse zeigen, dass die wahrgenommen Risiken sowohl den positiven Zusammenhang zwischen wahrgenommenden Chancen und einer prospektiven strategischen Orientierung als auch den negativen Zusammenhang zwischen wahrgenommenen Chancen und einer defensiven strategischen Orientierung verstärken. Die Implikationen der vorliegenden Erkenntnisse auf die Gestaltungsperspektive der institutionellen Theorie werden ebenso diskutiert wie Leitlinien für die zukünftige Forschung.

Keywords: institutional change, threats and opportunities, Romania, entrepreneurial cognition, strategic orientations

\footnotetext{
* Manuscript received: 18.01.12, accepted: 20.01.13 (2 Revisions)

** Oana Cătălina Iederan: COGNITROM, Romania \& Department of Psychology, "Babeş-Bolyai" University, Cluj-Napoca, Romania

Petru Lucian Curşeu: Department of Organisation Studies, Tilburg University, Tilburg, The Netherlands

Patrick A.M. Vermeulen Radboud University, Institute for Management Research, The Netherlands

Jac L. A. Geurts. Department of Organisation Studies, Tilburg University, Tilburg, The Netherlands
} 


\section{Introduction}

Organizations in East European countries faced important institutional changes in the last decades (Buhovac \& Groff, 2012). Romanian organizations have undergone two processes of institutional change: (1) the shift towards a free market economy following the abolition of the communist regime and (2) the integration into the European Union (Chiaburu, 2006; Catana \& Catana, 2012). Prior research has to a certain extent explored the way in which Romanian organizations cope with the transition process (Chiaburu, 2006; Iederan et al., 2011), yet little to no research has explored the way in which the institutional changes associated with the economic transition influence the strategic orientation of Romanian SMEs. We use institutional theory to explore the association between the framing of institutional changes and the strategic orientations of SMEs.

SMEs occupy strategic positions and assume a leading role in the economic development of many countries, including Romania (Audretsch et al., 2009; Jansen et al., 2013; OECD, 2005). However, Romanian SMEs, as well as those from other CEE countries, have been confronted with important challenges brought by the EU integration: increased competition due to market globalization, the corroboration of the Romanian and EU legislation, the foundation of new governmental structures to deal with, the access to EU funds etc. (Buhovac \& Groff, 2012). In such a complex and dynamic environment, a firm's strategic orientation is a key factor for the success of the company (Hambrick, 1983) and for its very survival on the market (Thomson, 2001). By strategic orientation we mean the company's response to environmental pressures such as competitors, technology, customers, rules and regulations that result out of the strategic choices made by key organizational actors.

Recent developments in institutional theory address the way institutions change over time as well as the manner in which such changes may have a differential influence on organizational action and strategy (George et al., 2006; Pache \& Santos, 2010; Greenwoodet al., 2011). Although we acknowledge the importance of institutions and the enduring influence of institutions on organizations (Nee, 2005), we contribute to the recent stream of research in organizational institutionalism (Greenwood, Oliver, Suddaby \& Sahlin, 2008) by arguing that the interplay of perceived opportunities and threats associated with a particular institutional change impacts on SMEs strategic orientations. Hence, within the constraints imposed by institutions, actors have a degree of agency, which they can deploy for strategic responses to institutional pressures (cf. Oliver, 1991). In SMEs the link between cognition and strategy is particularly tight since strategic decisions (SDM) are often made by leading entrepreneurs alone and decision making support systems are underdeveloped and rarely implemented (Brouthers et al., 1998; Miller et al., 1982; Mintzberg \& 
Waters, 1982). As such, an important aspect of entrepreneurial cognition in SDM processes is the way in which entrepreneurs perceive and assess environmental changes (Iederan et al., 2009) - as opportunities or threats. In particular, we contend that organizational strategies may vary as a function of the interplay of perceived threats and opportunities embedded in the institutional change, even when organizations are confronted with similar institutional pressures.

Therefore, our contribution to the literature on strategic orientations in SMEs is threefold: (1) we extend the threat rigidity hypothesis by considering not only the independent effect of perceived threats and opportunities, but also including their interaction; (2) we bridge the literature on managerial cognition, institutional change and strategic orientations and (3) we use insights from managerial cognition to further explore the drivers of SMEs' strategic orientations.

\section{Theoretical framework}

Strategic orientation focuses on the way a company interacts with its environment (Day, 1994; Gatignon \& Xuereb, 1997). As such, a firm's strategic orientation refers to a stable pattern of strategic actions related to the structure and functioning of a firm (Conant et al., 1990) and describes the fit between the firm's strategic choices and the environment. A good fit between the characteristics of the environment and the chosen strategy, increases the company's performance (Meier et al., 2007). Miles and Snow (1978) argued that different strategy types can be identified when companies try to align with environmental constraints and/or opportunities, namely: defenders, prospectors, analyzers and reactors (Conant et al., 1990).

Defenders are mature companies operating in a mature industry. They seek to protect their position in the economic environment by cost control, efficient production through established and standardized technical processes, continuity of products in "their specialized area" and reliability. Defender strategies are associated with an increased reliance on historical precedents and already tested routines, leaving little room to outcome uncertainty (Rajagopalan, 1996).

In contrast, prospectors are flexible (less bureaucratic) companies that seek to exploit the environmental opportunities by developing new products and/or services and approaching new markets. The leading role in implementing this strategy is held by the marketing and R\&D departments that encourage creativity and innovation over efficiency in order to create and meet new customer demands. Overall, prospectors are associated with fewer wellestablished routines, with multiple options in terms of actions and more outcome uncertainty (Rajagopalan, 1996). 
Analyzers are hybrid companies and combine strategy elements from both prospectors and defenders. Similar to the defenders, they prefer to avoid unnecessary risk by concentrating on a limited range of products and technologies and outperform competitors through quality enhancement. However, in line with the prospectors, they are ready to adopt innovations with proven market potential when confronted with more turbulent environments. Reactors have little control over the environment; they fail to adapt to external competitors and lack effective internal control mechanisms. They have no systematic strategy or structure (Miles \& Snow, 1978).

Most of the research to date on strategy regulation in response to environmental pressures has been conducted in mature, market driven economies. Little is known about the impact of institutional pressures upon organizational actions within emerging economies (Chittoor et al., 2008; Iederan et al., 2011). Compared to the relatively stable economic systems in Western markets, institutional transitions in emerging economies are "qualitatively different" (Newman, 2000: 602). During institutional change processes established norms, structures, values and models for actions are challenged (Greenwood, Suddaby \& Hinings, 2002). The change in norms, structures and values is even more pervasive throughout emerging economies, which are defined by a rapid growth along with political and economic uncertainty (Kostera, 1995; Catana \& Catana, 2012) and such changes are believed to impact the company's strategy more severely (Meyer et al., 2009).

Understanding managerial interpretations of complex institutional environments is essential for understanding organizational (strategic) actions (George, et al., 2006; Iederan et al., 2009). In line with George et al. (2006) we argue that the specific markers of the defender strategy as identified by Miles and Snow (1978) match the isomorphic type of organizational response to the environment. An isomorphic reaction basically aims to preserve the status quo within the company and the economic environment through the adoption of similar structures (Fligstein, 1985), practices (Mezias, 1990) and rhetoric (Elsbach \& Sutton, 1992). The departure from well-established structures and practices specific to the prospector strategy is an indicator of an organization's nonisomorphic response to the external environment. Non-isomorphic reactions of the prospector companies involve challenging the 'old ways' specific to similar organizations on the market, while coming up with new structures, procedures and products, thus setting the ground for new legitimate forms (Cardinal et al., 2004; George et al., 2006;).

As core decision makers, entrepreneurs are likely to form simplified images of a macro-level situation of institutional change that will be translated either as an opportunity framing, or as a threat framing (Dutton \& Jackson, 1987; Jackson \& Dutton, 1988; Iederan et al., 2011). Threats are referred to as 'a negative situation in which loss is likely and over which one has relatively little control', 
while opportunities stand for 'a positive situation in which gain is likely and over which one has a fair amount of control' (Dutton \& Jackson, 1987:80). Through their sense of urgency and difficulty, both opportunities and threats are salient concepts in SDM and are likely to evoke specific forms of organizational actions (George et al., 2006) corresponding to the adequate strategy type that would allow the company to co-align with the environmental opportunities or constraints (Miles \& Snow, 1978). Thus, in line with the strategic choice perspective (Child, 1972; 1997), we argue that the way entrepreneurs of SMEs perceive the environment in terms of opportunities and/or threats plays a role in the strategic orientation of the company.

Institutional pressures are rarely positive or negative per se. They are multidimensional since they refer to resources acquisition, stakeholder alignment or legitimacy attainment (Baum \& Oliver, 1991) and seldom entail only opportunities or only threats for SMEs. While institutions are usually the "rules of the game" and function as an uncertainty inhibitor for the organizational actors (DiMaggio \& Powell, 1983), during times of institutional change, established structures and rules are challenged and new 'rules of the game' emerge. The dynamics of institutional change derive from continuous interaction between institutions and organizations with vested interests that reinforce established rules that make it difficult for individual organizations to implement changes (Nee, 2005) or act rationally by maximizing individual utility functions (cf. Smelser \& Swedberg, 2005).

Institutional change is also defined by ambiguity, a lower level of predictability and conflicting norms, values and beliefs (cf. Newman, 2000; Greenwood et al., 2011). Institutional change often leads organizations to be confronted with multiple, contrasting demands from key constituents, which creates a situation of institutional complexity (Greenwood et al., 2011). The way organizations deal with this complexity is little understood (Pache \& Santos, 2010). As such, organizational action is also dependent upon the way key decision makers within SMEs perceive and assess changes in the institutional environment (Townsend \& Hart, 2008). Whereas this does not provide individual organizations with unlimited possibilities to pursue their self-interest, it does allow organizations to strategically respond to institutional changes (cf. Oliver, 1991; Pache \& Santos, 2010; Greenwood et al., 2011).

Evidence suggests that in a situation of institutional change, SMEs' decision makers might be confronted with a mixed reading of the environment and an event may simultaneously be categorized as a threat and an opportunity (Cacioppo \& Berntson, 1994). Simultaneously invoking two categories to describe an event is more likely when categories are related or overlapping (Ross \& Murphy, 1996) as in the case of opportunities and threats (George et al., 2006; Jackson \& Dutton, 1988). 
As outlined in the research context section, the European Union integration is a particular case of institutional change that brings major transformation at several levels of a state's functioning with major implications for organizational actors. According to the salience and availability of environmental clues and the processing abilities of the entrepreneur, institutional change can be interpreted as including both threats and opportunities. These intertwined perceptions are subsequently reflected in the strategic orientation of the SME.

To summarize, when considering a complex institutional change (George et al., 2006) such as Romania's ascension to the EU, it is essential to explore the way in which perceived threats and opportunities are associated to a specific organizational response and strategic orientation. When the institutional change is simultaneously categorized as bringing along both opportunities and threats, we argue that perceived threats increase the positive association between perceived opportunities and the prospector strategic orientation. That is, in a high opportunity environment, the more threats an entrepreneur perceives, the more likely he is to make strategic decisions in line with a prospector nonisomorphic strategy in order to meet the environmental demands. This would also be consistent with Campbell (1965) and Weick's (1979) findings that a flexible and diverse response might have a survival value when an individual is confronted with radical environmental changes, since prior well-learned routines might not be appropriate under new conditions (Staw, Sandelands and Dutton, 1981).

Moreover, when institutional change (IC) is simultaneously categorized as containing both opportunities and threats, we argue that perceived threats increase the negative association between the perceived opportunities and the defender (isomorphic) strategy. That is, an entrepreneur is less likely to adopt a defender style in a high opportunity environment and this tendency is emphasized by the increasing perception of threat. On the other hand, a defender, isomorphic type of strategy, will be more suited for a low opportunity environment associated with different levels of perceived threats, since it would help preserve the company's status quo and consolidate its position in the economic environment affected by institutional change. This is in line with findings at the individual level which state that risk-taking behavior is more beneficial if taking place in a high opportunity environment (Chattopadhyay et al., 2001), while in the absence of opportunities and when confronted with a threatening situation, a rigid but previously successful action of an individual is a functional, adaptive reaction (Staw et al., 1981). We formulate the following hypothesis:

$\mathrm{H}$ : Perceived threats moderate the impact of perceived opportunities on SMEs strategic orientation in such a way that perceived threats increase the positive association between perceived opportunities and the prospector 
strategic orientation, as well as the negative association between the perceived opportunities and defender strategic orientation.

\section{Research context}

Following the fall of the communist regime in the early '90s and the so-called transition, Romania, along with other CEE countries, has embarked in a complex process of institutional upheaval driven by the intention to adhere to the EU structures. Between December 1999, when Romania officially signed in for the EU ascension, and January $1^{\text {st }} 2007$, an extensive plan of reform had to be initiated with respect to all the major sectors of a state's functioning: social, economical, judiciary, political and military in order to submit to the so-called "Copenhagen criteria" set out in December 1993 by the European Council. The candidate countries must have: 1) stable institutions that guarantee democracy, the rule of law, human rights, respect and protection for minorities; 2) a functioning market economy, as well as the ability to cope with the pressure of competition and the market forces inside the EU; 3) adherence to and the ability to put into practice the EU objectives of economic, political and monetary union.

As such, Romania engaged in an administrative and fiscal decentralization process, prices were freed and started to align to European standards, currency was revalued and previously state-owned enterprises entered a privatization process. Laws and regulations were revisited and adjusted to EU standards; the judiciary system was subject to major reform.

Once Romania was granted EU membership in 2007, change in formal and informal institutions continued. Customs were dissolved and the free circulation of products and labor force within EU borders achieved. Moreover, European companies entered the local market and lead to an increased competition for local companies. Access to EU funding was provided for Romanian companies, as well as the access to success business models and know-how from the "outside" (Iederan et al., 2011).

These changes were even more pervasive in the case of Romania, which meets the major particularities of an emerging economy (cf. Kostera, 1995; Hoskisson et al., 2000). The ambiguity of the integration in the EU structures as an institutional change, resides in the change of the "old rules of the game" by the alignment to the EU standards, along with the measures that brought both constraints (e.g. change in fiscal policy) and opportunities (e.g. access to EU funding) (Iederan et al., 2011).

\section{Methods}

\section{Sample}

The target group for collecting the data comprised entrepreneurs of Romanian micro, small and medium sized enterprises. The admission criteria for entering 
the study were that: (1) the company qualifies as an SME according to the European Commission of Industry and Commerce - it is autonomous, has less than 250 employees, a turnover of less than 50 million Euros or a balance sheet total of less or equal to 43 million Euros, (2) the company had economic activity for at least one year before the data collection procedure took place, and (3) the SMEs' entrepreneurs are actively involved in decision making processes regarding the firm's strategy on the market. Moreover, in order to increase the generalizability of our findings, SMEs operating in multiple industries such as commerce $(39.4 \%)$, construction $(8.2 \%)$, production $(10.2 \%)$, IT $(13 \%)$, consultancy $(15.1 \%)$, services $(8.1 \%)$, other $(6 \%)$ were included in the study.

The non-probabilistic sampling procedure used in this study was the snowball technique described by Baker (1999). Prior to actually collecting the data, a number of Romanian SMEs in each of the following industries were marked as the ones to begin with: commerce, real estate, IT, consultancy, financial services, HORECA, production, construction, transportation. Each entrepreneur in our sample was asked to recommend other potential respondents from the same industry as well as from other industries, as long as they met the preset study conditions. By explicitly asking the respondents to point out to other respondents with the same characteristics, but different backgrounds, we tried to avoid a too homogenous sample in order to enhance its representativeness and to extend the generalizability of our findings (Baker, 1999)

More than 370 SMEs entrepreneurs were originally contacted by mail or face to face and asked to join the study and a sample of 325 Romanian entrepreneurs were included in the study.

\section{Instruments and Data Collection}

The data were collected 2 to 2.5 years after the Romania's EU integration (May - July 2009), as the institutional pressures associated with the EU ascension need time to "settle in" (Iederan et al., 2011). The participants were asked to fill in a questionnaire that included measures for all the variables in the study, as well as information about demographics. The summary of the items included in the questionnaire is presented in Table 1.

Table 1 A summary of the scales included in the analyses

\begin{tabular}{|l|l|l|}
\hline Scale & $\begin{array}{c}\text { No of items } \\
\text { (Cronbach's } \\
\text { alpha) }\end{array}$ & \multicolumn{1}{|c|}{ Items } \\
\hline $\begin{array}{l}\text { Opportunity } \\
\text { scale }\end{array}$ & $3(.74)$ & $\begin{array}{l}\text { The integration in the EU generated new development } \\
\text { opportunities for my company. } \\
\text { The integration in the EU brought new clients and business } \\
\text { opportunities for my company. } \\
\text { The integration in the EU brought more efficient business }\end{array}$ \\
\hline
\end{tabular}




\begin{tabular}{|l|l|l|}
\hline Threat scale & $3(.73)$ & $\begin{array}{l}\text { and development models for my company. } \\
\text { my company. } \\
\text { The integration in the EU facilitated the penetration of } \\
\text { foreign competitors on the Romanian market, that are } \\
\text { much stronger than my company. } \\
\text { The integration in the EU enhanced the legal constraints } \\
\text { that govern my company's field of activity. }\end{array}$ \\
\hline $\begin{array}{l}\text { Strategic } \\
\text { orientation } \\
\text { scale (Conant } \\
\text { et al., 1990) }\end{array}$ & $11\left(^{*}\right)$ & $\begin{array}{l}\text { In comparison to other SMEs, the increase or losses in } \\
\text { demand which we have experienced are due most probably } \\
\text { to: (a) Our practice of concentrating on more fully } \\
\text { developing those markets which we currently serve (D); (b) } \\
\text { Our practice of responding to the pressures of the } \\
\text { marketplace by taking few risks. (R); (c) Our practice of } \\
\text { aggressively entering into new markets with new types of } \\
\text { service offerings and programs. (P); (d) Our practice of } \\
\text { assertively penetrating more deeply into markets we } \\
\text { currently serve, while adopting new services only after a } \\
\text { very careful review of their potential (A) }\end{array}$ \\
\hline SME details & $2\left(^{* *}\right)$ & $\begin{array}{l}\text { age, gender, education level, experience of the entrepreneur } \\
\text { (operationalized as number of years of experience as an } \\
\text { entrepreneur) }\end{array}$ \\
\hline Demographic & $4\left(^{* *}\right)$ & $\begin{array}{l}\text { activity sector, organization size (operationalized as the } \\
\text { number of employees) }\end{array}$ \\
\hline
\end{tabular}

Notes: *alpha coefficients for the strategic orientation scales are not computed since the variables are categorical and for the sake of brevity we do not report the whole scale; ** alpha coefficients for these variables were not computed as they were used as single items in the analyses.

Given the nature of the hypotheses and the structure of the data, we used OLS regression to analyze the data. We followed the procedure described in Aiken and West (1991) for testing interaction effects.

\section{Results}

Table 2 presents descriptive statistics and correlations among the variables. 


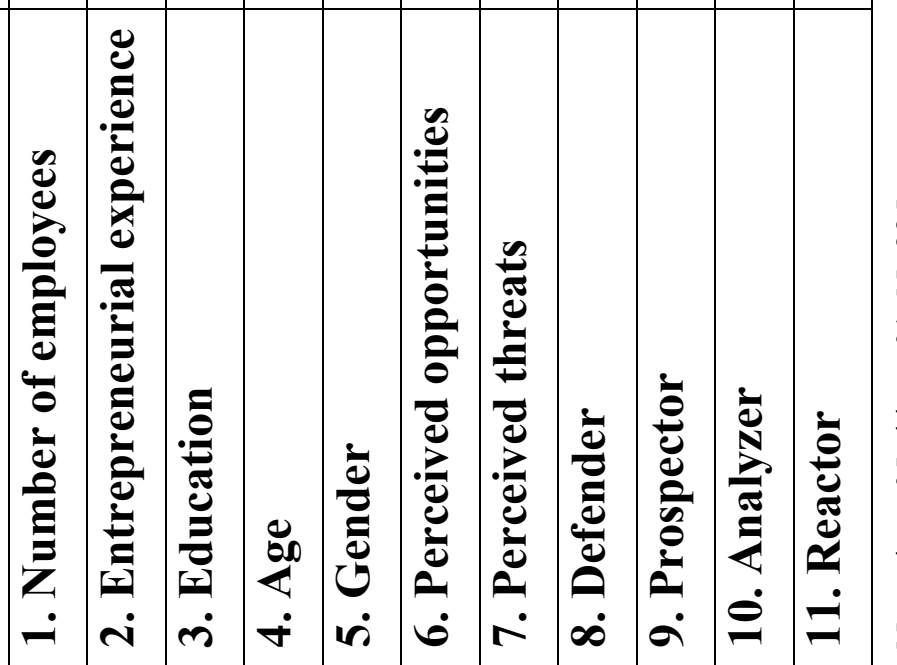


There were significant positive correlations between the level of perceived opportunities by the entrepreneurs and organization size $(\mathrm{r}=.11, \mathrm{p}<.05)$, between the level of perceived threats and entrepreneurs' age $(\mathrm{r}=.13, \mathrm{p}<.05)$ and entrepreneurial experience $(\mathrm{r}=.11, \mathrm{p}<.05)$. Moreover, a defender style is negatively associated with the perceived level of opportunities $(r=-.15, p<.01)$, whereas a prospector strategy is positively associated with education $(\mathrm{r}=.11$, $\mathrm{p}<.05)$ and the perceived level of opportunities $(\mathrm{r}=.28, \mathrm{p}<.01)$, and negatively associated with the perceived level of threats $(\mathrm{r}=-.48, \mathrm{p}<.01)$,

We performed several OLS regression analyses to formally test the moderation hypothesis. In all the OLS regressions, sector (dummy variable), organization size (operationalized as the number of employees), education (operationalized as the highest education level attained by the entrepreneur), age, entrepreneurial experience and gender were introduced as control variables in the first step. Perceived threats and perceived opportunities associated with the institutional change were entered in the second step and the cross product term between the two was entered in the third step. In order to reduce multicolinearity, the scores for opportunities and threats were grand mean centered before the analyses and the cross product term was computed after centering (Aiken \& West 1991). The results of the OLS regression analyses are presented in Table 3. 


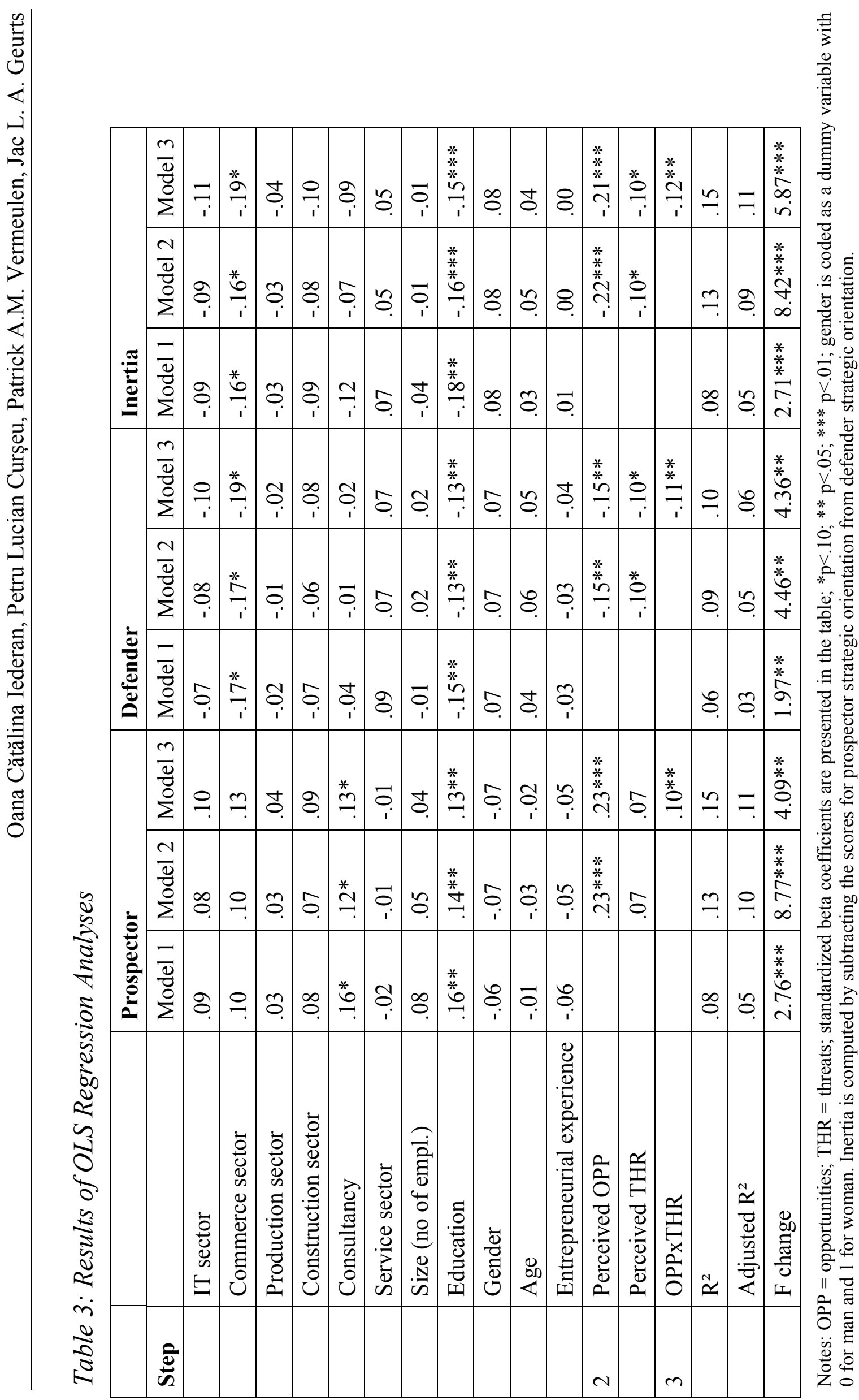


The hypothesis that perceived threats moderate the impact of perceived opportunities on SMEs strategic orientation in such a way that perceived threats increase the positive association between perceived opportunities and the prospector strategic orientation, as well as the negative association between the perceived opportunities and defender strategic orientation was fully supported (see Table 3 and also Figures 1 and 2 for the illustration of the interaction effects).

Figure 1: Interaction Effects between Opportunities and Threats on the Defender Strategy

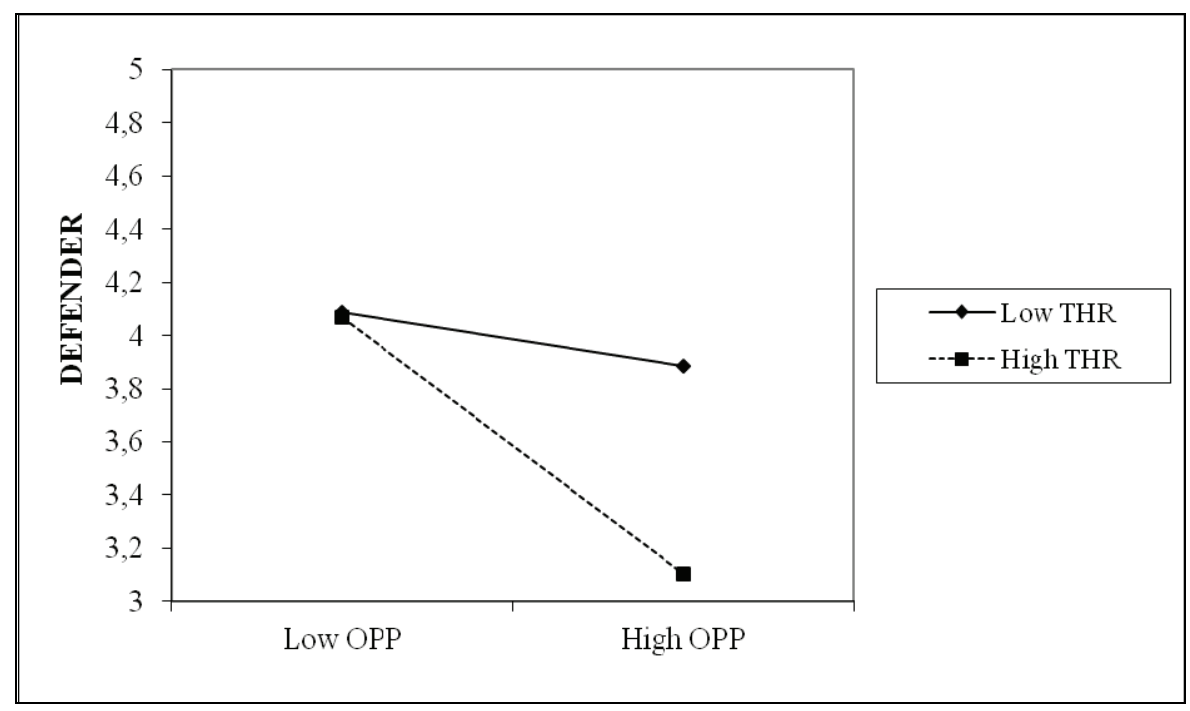

Figure 2: Interaction Effects between Opportunities and Threats on the Prospector Strategy

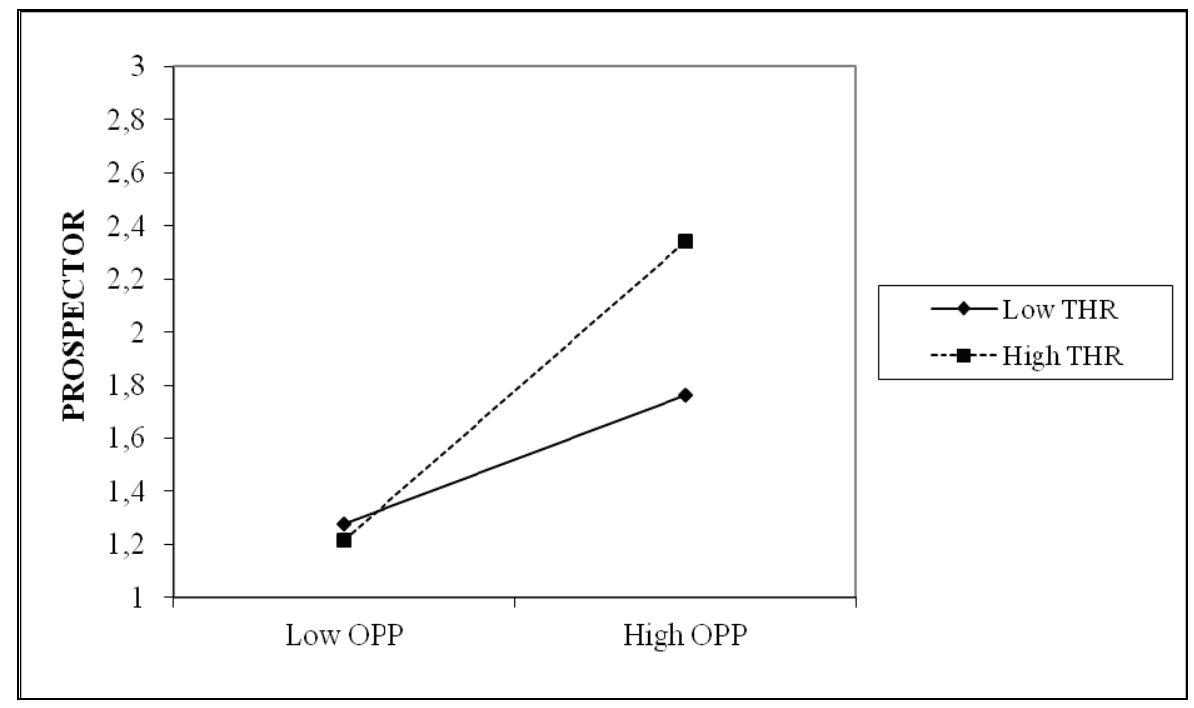

In order to further explore the interaction effect we have computed an inertia score (by subtracting the prospector score from the defender score), indicative of 
the extent to which an SME preserves the status quo as opposed to change (see Figure 3).

\section{Figure 3: Interaction Effects between Opportunities and Threats on Inertia}

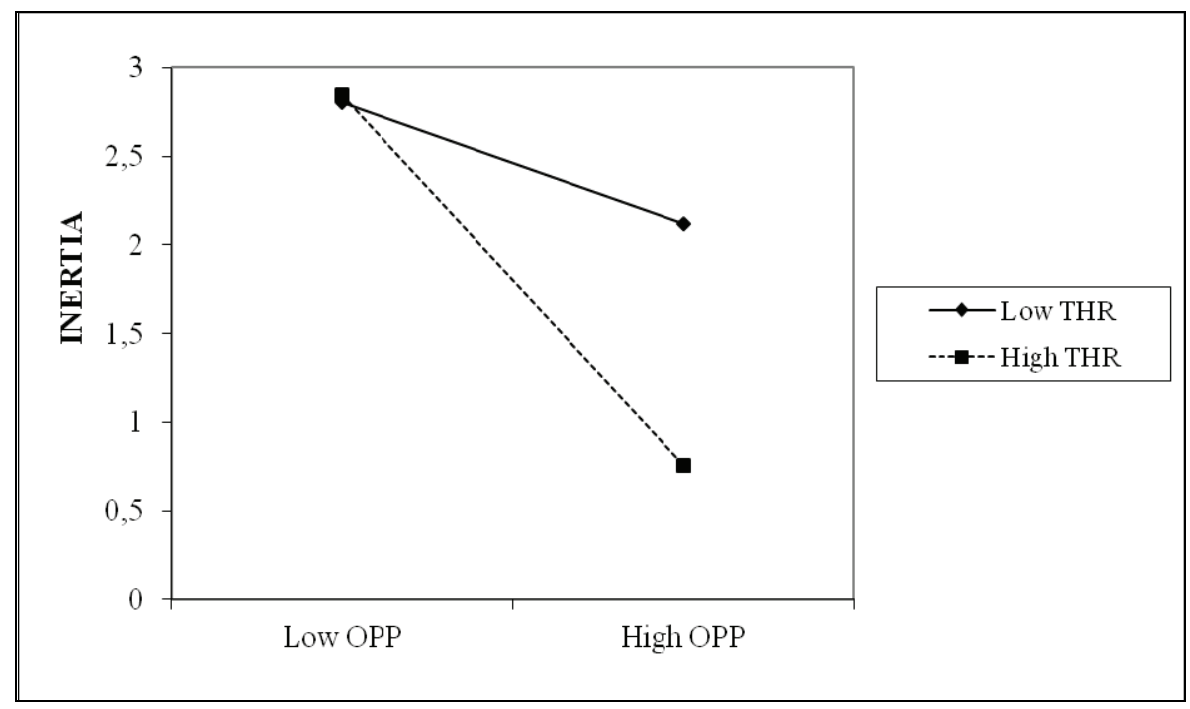

The cross product terms of perceived opportunities and perceived threats associated with the institutional change is significant for prospector strategic style $(\beta=.10, \mathrm{p}<.05)$, defender strategic style $(\beta=-.11, \mathrm{p}<.05)$ and inertia $(\beta=-.12$, $\mathrm{p}<.05)$, indicating the importance of the interplay between perceived threats and opportunities in predicting the strategic orientation of the SME.

We have controlled for demographic variables, entrepreneurial experience and activity sector. Beta coefficients for sectors indicate that there might be a sector dependency of some of the strategic types. A defender strategy seems unlikely to occur $(\beta=-.19, \mathrm{p}<.10)$ in the commerce sector, while the prospector strategy seems to be more common $(\beta=.13, p<.10)$ in the consultancy sector. Moreover, inertia is less likely to appear in the commerce $(\beta=-.19, p<.05)$ sector. Education is positively associated with the prospector $(\beta=.13, p<.05)$ and negatively with defender $(\beta=-.13, \mathrm{p}<.05)$ strategic orientations.

Because we used newly developed scales to evaluate threats and opportunities, and the results may suffer from measurement errors, we used a latent variables approach to further analyze the data. The use of latent variables in Structural Equation Modeling (SEM) reduces the measurement error inherent to most instruments used in social sciences (Yuan \& Bentler, 2004; Curşeu \& Schruijer, 2012). Most of the control variables included in the OLS analyses had no significant relation with the two strategic orientations. Therefore in order to prevent the drawbacks of using misspecified models in SEM, we only used the scores for the threats, opportunities and the cross product term in our analyses. Therefore we used two latent factors (threats and opportunities) to predict the prospector strategic orientation (Model 1), the defender strategic orientation (Model 2) and inertia (Model 3). The results of the SEM and the fit indices for the three models are presented in Table 4. The absolute fit indices $\left(\chi^{2}\right.$ and 
RMSEA) show that the hypothesized model is not significantly different from the data and the incremental fit indices (CFI and TLI) show that the model cannot be significantly improved (using the conservative cut-off points specified in Yuan and Bentler, 2004). We can therefore conclude that the results of the latent variables approach fully support the results of the OLS regression analyses as reported in Table 3.

Table 4: Results of the SEM analyses with two latent variables and the cross product term

\begin{tabular}{|c|c|c|c|c|c|c|c|}
\hline Model & Path & $\begin{array}{l}\text { Coefficient } \\
\text { (p) }\end{array}$ & $\begin{array}{c}\chi^{2}(\mathbf{d f}), \\
\mathbf{p}\end{array}$ & NFI & TLI & CFI & RMSEA \\
\hline \multirow[t]{3}{*}{ Model 1} & $\begin{array}{l}\text { Prospector<--- } \\
\text { THRxOPP }\end{array}$ & $.22(.003)$ & \multirow{3}{*}{$\begin{array}{c}26.29 \\
(17) \\
p<.07\end{array}$} & \multirow{3}{*}{.98} & \multirow{3}{*}{.99} & \multirow{3}{*}{.99} & \multirow{3}{*}{.042} \\
\hline & $\begin{array}{l}\text { Prospector }<--- \\
\text { THR }\end{array}$ & $-.10(.05)$ & & & & & \\
\hline & $\begin{array}{l}\text { Prospector }<--- \\
\text { OPP }\end{array}$ & $.17(.002)$ & & & & & \\
\hline \multirow[t]{3}{*}{ Model 2} & $\begin{array}{l}\text { Defender }<--- \\
\text { THRxOPP }\end{array}$ & $-.16(.02)$ & \multirow{3}{*}{$\begin{array}{c}27.54 \\
(17) \\
p<.06\end{array}$} & \multirow{3}{*}{.98} & \multirow{3}{*}{.98} & \multirow{3}{*}{.99} & \multirow{3}{*}{.048} \\
\hline & $\begin{array}{l}\text { Defender<--- } \\
\text { THR }\end{array}$ & $.02(.70)$ & & & & & \\
\hline & $\begin{array}{l}\text { Defender<--- } \\
\text { OPP }\end{array}$ & $-.08(.17)$ & & & & & \\
\hline \multirow[t]{3}{*}{ Model 3} & $\begin{array}{l}\text { Inertia<--- } \\
\text { THRxOPP }\end{array}$ & $-.22(.003)$ & \multirow{3}{*}{$\begin{array}{c}27.71 \\
(17), \\
p<.05\end{array}$} & \multirow{3}{*}{.98} & \multirow{3}{*}{.99} & \multirow{3}{*}{.99} & \multirow{3}{*}{.044} \\
\hline & $\begin{array}{l}\text { Inertia<--- } \\
\text { THR }\end{array}$ & $.07(.19)$ & & & & & \\
\hline & $\begin{array}{l}\text { Inertia<--- } \\
\text { OPP }\end{array}$ & $-.14(.01)$ & & & & & \\
\hline
\end{tabular}

Notes: OPP = opportunities; THR = threats; standardized path coefficients are presented in the table; Inertia is computed by subtracting the scores for prospector strategic orientation from defender strategic orientation.

\section{Discussion}

The aim of this study was to explore what type of organizational strategy will emerge as a result of a specific pattern of interpreting complex environmental features pertaining to a situation of institutional change. Considering the vast 
areas of organizational functioning afflicted by an institutional change as well as the multiple outcomes it can generate, we argued that key decision makers within SMEs perceive such macro-level environmental changes as bringing along both opportunities and threats for their companies, depending on the salience and interplay of related environmental clues. These specific representations of the institutional pressure elaborated by the decision makers would in turn influence the way they react to them and ultimately define the strategic orientation of their companies.

In line with previous research (Jackson \& Dutton, 1988; Cacioppo \& Berntson, 1994; Priester \& Petty, 1996; Spicer et al., 2000) we highlighted that multiple categorizations of the same event can occur when ambiguous institutional changes are interpreted as bringing both opportunities and threats. That is, in order to confront the ambiguity stemming from the changing norms, values and structures brought about by the EU integration, Romanian entrepreneurs elaborated cognitive representations of the institutional change according to the information at hand. Some of them perceived the integration as bringing along a significant amount of both opportunities and threats, while others represented less information pertaining to these categories.

Furthermore, we have pointed out that entrepreneurs of SMEs who are subject to such a mixed reading of an institutional change are more prone to act in a prospector style when they perceive more opportunities within the economic environment and this propensity increases with the associated perception of significant levels of threat.

High levels of perceived opportunities and threats are specific markers of institutional changes that include alteration of previous constraints, laws, government policies and regulations, the emergence of new customer demands and environmental trends. Our study points out that in order to optimally respond to these environmental particularities entrepreneurs are more likely to employ a prospector type of strategy. The perceived existence of opportunities drives entrepreneurs to make strategic decisions that promote new, unprecedented courses of action, because acknowledging and trying to take advantage of them is associated with a sense of control over the situation (George et al., 2006). Moreover, the associated perception of high levels of threat will only make this propensity stronger. High levels of threat are indicative of fundamental shifts in the organizational environment, and, in line with the threat-rigidity hypothesis (Staw et al., 1981), the dominant response might not be adaptive under the new circumstances. Thus, entrepreneurs depart from pre-existing routines and instead develop a new and more customized repertoire of actions. Also, the pressure to conform (DiMaggio \& Powell, 1983) might be perceived as weaker in times of institutional change. 
Unlike other similar companies, prospectors will structure their organization in a flexible, environment-oriented manner, where collaboration among departments is required and decisions and actions are decentralized. The prospectors' goal is to stay in close touch with the economic environment, encouraging innovation and flexibility within the organization to swiftly respond to opportunities and launch new products and services (Miles \& Snow, 1978).

The departure from inertia and the preference for non-isomorphic actions is more typical for organizations operating in commerce, IT and consultancy. Consultancy companies are more prone to challenge the status quo, innovate and embrace diversified action patterns in order to satisfy their clients. Currently, consultancy is a dynamic sector in Romania, with foreign competitors bringing successful business models (opportunities for development), as well as serious threats due to their higher financial power (Iederan, et al., 2011). Therefore, both threats and opportunities present in this sector could explain the strong preference of entrepreneurs in consultancy for prospector strategies. In other words, the co-occurrence of both threats and opportunities in the Romanian consultancy sector forces these companies to actively search for alternative ways to survive on the market: developing of new products or providing different services. Another significant sector level effect is found in commerce, where the defender strategy is less prevalent compared to other sectors. Iederan and colleagues (2011) argue that the EU integration is predominantly perceived as threatening by organizations in the commerce sector, especially due to the strict new EU regulations organizations in this sector have to comply with. These new rules and regulations force organizations in the commerce sector to change their routines and break with their historical precedents.

The organizations' non-isomorphic behavior as an effective coping mechanism to a dynamic environment is also supported by research at the individual level. The latter implies that reacting in a rigid and isomorphic way to major environmental changes is maladaptive (Staw et al., 1981). In these particular circumstances, a flexible and diverse response is a more functional approach and has a superior survival chance (Campbell, 1965; Weick, 1979).

The results of the current study also show that entrepreneurs who grasp few opportunities associated with the institutional change are more risk-averse and thus less likely to promote non-isomorphic strategies. The lack of opportunities acts as an inhibitor for the promotion of major change in the company routines. As such, entrepreneurs will try to preserve the status-quo of their SMEs by acting in a defender style. Basically, the environmental clues pertaining to the institutional change that are incorporated by SMEs in a low opportunity framing further act as environmental clues that existing procedures are still valid. As such, entrepreneurs will implement a defender style, promoting mimicry and acting in an isomorphic manner, probably in an attempt to maintain their legitimacy on the market. This means that they are likely to make strategic 
decisions that promote previously well-learned routines, already proven in terms of efficacy.

This propensity for the defender strategy increases with the associated perception of threats. When the entrepreneurs' reading of the environment is dual in nature, they are confronted with more difficulty in processing new and complex information pertaining to the institutional change. As a result, they will tend to rely even more on past experience and knowledge (Staw et al., 1981; D’Aunno \& Sutton, 1992).

The rationale behind such an organizational inertia might be provided by the outputs of individual level research which stress the fact that under conditions of low threat (threat does not involve major environmental change) an individual will be more prone to act rigidly, by making appeal to well-learned routines, and a dominant response proves to be a functional way of approaching minor threatening situations (Staw et al., 1981).

Coming back to the research question: how will organizations behave when confronted to a pervasive, ambiguous institutional change? A plausible answer is that individual cognition of decision makers in SMEs could act as a mediator between institutional pressures on the one hand, and the strategic orientation of an SME on the other hand (Iederan et al., 2009; Jansen et al., 2013). Moreover, the ambiguity of institutional change seems to promote a considerable variation in organizational behavior, in that different types of representations developed by decision makers with respect to institutional change are associated with particular sets of strategic choices and ultimately with different organizational strategies. Entrepreneurs who develop a low opportunity framing of the institutional environment are likely to employ a defender strategy and act in an isomorphic manner and this propensity increases with the associated level of perceived threats. On the other hand, a high opportunity representation is associated with a variety of responses that defines the non-isomorphic prospector strategy and this link is further tightened with the increased perception of threats.

\section{Limitations}

Besides the contribution of this research, inherent limitations advise towards a cautious interpretation of the results. Although we have tried to ensure a diverse and representative sample through the study admission criteria and Baker's nonprobabilistic sampling technique (1999), the sample might still not be illustrative for the whole SME population in Romania.

Further on, the results clearly indicate an association between the type of framing of the environment - as containing high versus low opportunities and threats - and the type of strategy employed - prospector versus defender. Still, the cross-sectional design does not allow for clear causal reasoning. Thus, future 
research could further investigate the existence of a causal liaison between the entrepreneurs' framing of the environment and the chosen strategy for the SME. Moreover, as the $\mathrm{R}^{2}$ values reported in Table 3 are rather low, future research should investigate other antecedents of strategic orientations in SMEs.

The third limitation could be related to the rather small time scale in relation to the IC. Most studies explore the impact of IC on rather long time span, while for this study, only a few years have passed since the IC. In the light of the hypotheses this is, however, not a major issue since we are exploring entrepreneurial cognition in a situation of IC and the proximity of institutional change reduces the chance of post-evaluation and memory biases in our research.

Finally, our study focuses on strategic orientation and future research could explore the way in which perceived opportunities and threats further impact on organizational performance. For example, it is not unreasonable to assume that strategic orientations mediate the impact of perceived opportunities and threats on organizational performance.

\section{Conclusions}

To conclude, the results of our study suggest the importance of understanding the way cognitive representations of complex environmental settings impact the strategic orientations of SMEs operating in various industries. Our findings also go one step further than previous research (Staw et al., 1981; George et al., 2006) and clearly highlight the fact that complex environments (e.g., macro institutional changes) generate multidimensional frames and are interpreted as bringing along both opportunities and threats. Thus our study departs from the threat-rigidity hypothesis and outlines the importance of also considering the interaction of perceived threats and perceived opportunities in determining a specific course of action at the individual or organizational level.

Moreover, we emphasize that individual cognition and strategic orientation are closely linked in the SME setting. Perceived threats moderate the impact of perceived opportunities on SMEs strategic orientation in such a way that perceived threats increase the positive association between perceived opportunities and the prospector strategic orientation, as well as the negative association between the perceived opportunities and defender strategic orientation. Further research could investigate the cognitive mechanisms that drive entrepreneurs towards the mixed reading of the environment.

All in all, our study stresses once again, the role of entrepreneurs who act as "cognizers" and are responsible for interpreting the complex environment and providing the company with a strategic orientation in accordance to the mental models created for specific institutional change. 


\section{References}

Aiken, L. S./ West, S. G. (1991): Multiple regression: Testing and interpreting interactions. Newbury Park, CA: Sage.

Audretsch, D./ van der Horst, R./ Kwaak, T./ Thurik, R. (2009): First Section of the Annual Report on EU Small and Medium-sized Enterprises

Baker, T. L. (1999): Doing social research. Boston: McGraw-Hill.

Baum, J.A.C./ Oliver, C. (1991): Institutional linkages and organizational mortality, in: Administrative Science Quarterly, 36, 2, 187-218.

Brouthers, K. D./ Andriessen, F./ Nicolaes, I. (1998): Driving Blind: Strategic decisionmaking in small companies, in: Long Range Planning, 31, 130-138.

Buhovac, A. R./ Groff, M. Z. (2012): Contemporary performance measurement systems in central and eastern Europe: A synthesis of the empirical literature, in: Journal for East European Management Studies, 17, 1, 68-103.

Cacioppo, J./ Berntson, G. (1994): Relationship between attitudes and evaluative space: A critical review, with emphasis on the separability of positive and negative substrates, in: Psychological Bulletin, 115, 401-423.

Campbell, D. T. (1965): Variation and selective retention in socio-cultural evolution, in H. R. Barringer, G. I. Blankesten and R. Mack (eds.): Social Change in Developing Areas, 19-49, Cambridge, MA: Schenkman.

Cardinal, L./ Sitkin, S./ Long, C. (2004): Balancing and rebalancing in the creation and evolution of organizational control, in: Organization Science, 15, 411-431.

Catana, D./ Catana, G. A. (2012): Continuity and change in Romanian societal culture dimensions, in: Journal for East European Management Studies, 17, 2, 226-249.

Chattopadhyay, P./ Glick, W. H./ Huber, G. P. (2001): Organizational actions in response to threats and opportunities, in: Academy of Management Journal, 44, 937-955.

Chiaburu, D. S. (2006): Managing organizational change in transition economies, in: Journal of Organizational Change Management, 19, 6, 738-746.

Child, J. (1972): Organization structure, environment and performance: The role of strategic choice, in: Sociology, 6, 1-22.

Child, L. (1997): Strategic Choice in the Analysis of Action, Structure Organizations and Environment: Retrospect and Prospect, in: Organization Studies, 18, 1, 43-76.

Chittoor, R./ Ray, S./ Aulakh, P. S./ Sarkar, M. B. (2008): Strategic responses to institutional changes: 'Indigenous growth' model of the Indian pharmaceutical industry, in: Journal of International Management, 14, 252-269.

Chreim, S. (2006): Managerial frames and institutional discourse of change: employee appropriation and resistance, in: Organization Studies, 27, 9, 1261-1287.

Conant, J. S./ Mokwa, M. P./ Varadarajan, R.P. (1990): Strategic types, distinctive marketing competencies and organizational performance: A multiple measures-based study, in: Strategic Management Journal,11, 365-383. 
Curşeu, P. L./ Schruijer, S. G. L. (2012): Decision styles and rationality: An analysis of the predictive validity of the General Decision-Making Style Inventory, in: Educational and Psychological Measurement, 72, 6, 1053 - 1062.

D'Aunno, T./ Sutton, R. T. (1992): The Response of Drug Abuse Treatment Organizations to Financial Adversity: A Partial Test of the Threat-Rigidity Thesis, in: Journal of Management, 18, 117-131.

Day, G. S. (1994): The capabilities of market-driven organizations, in: Journal of Marketing, $58,4,37-52$

DiMaggio, P. J./ Powell, W.W. (1983): The Iron Cage Revisited: Institutional Isomorphism and Collective Rationality in Organizational Fields, in: American Sociological Review,48, 147-160.

Dutton, J . E./ Jackson, S. E. (1987): Categorizing Strategic Issues: Links to Organizational Action, in: Academy of Management Review, 12, 1, 76-90.

Elsbach, K. D./ Sutton, R. I. (1992): Acquiring organizational legitimacy through illegitimate actions: A marriage of institutional and impression management theories, in: Academy of Management Journal, 31, 85-107.

Fligstein, N. (1985): The spread of multidivisional form among large firms, 1919-1979, in: American Sociological Review, 50, 377-391.

Gatignon, H./ Xuereb, J. M. (1997): Strategic orientation of the firm and new product performance, in: Journal of Marketing Research, 34, 77-90

George, E., P./ Chattopadhyay, B./ Sitkin, S./ Barden, J. (2006): Cognitive underpinnings of institutional persistence and change: A framing perspective, in: Academy of Management Review, 31, 2, 347-365.

Greenwood, R./ Suddaby, R./ Hinings, C.R. (2002): Theorizing change: The role of professional associations in the transformation of institutional fields, in: Academy of Management Journal, 45, 1, 58-80.

Greenwood, R./ Oliver, C./ Sahlin, K./ Suddaby, R. (2008): Introduction, in Greenwood, R., Oliver, C., Sahlin, K. \& Suddaby, R. (Eds.): The SAGE handbook of organizational institutionalism, London: Sage, 1-46.

Greenwood, R./ Raynard, M./ Kodeih, F./ Micelotta, E. R./ Lounsbury, M. (2011): Institutional complexity and organizational responses, in: Academy of Management Annals, 5, 1, 317-371.

Hambrick D. (1983): Some tests of the effectiveness and functional attributes of Miles and Snow's strategic types, in Academy of Management Journal, 26, 1, 5-26.

Hoskisson, R./ Eden, L./ Lau, C./ Wright, M. (2000): Strategy in emerging economies, in: Academy of Management Journal, 43, 249-267.

Iederan, O. C./ Curşeu, P. L./ Vermeulen, P. A./ Geurts, J. L. A. (2011). Cognitive representations of institutional change: Similarities and dissimilarities in the cognitive schema of entrepreneurs, in: Journal of Organizational Change Management, 24, 1, 928.

Iederan, O.C./ Curşeu, P.L./ Vermeulen, P.A.M. (2009): Effective decision-making: the role of cognitive complexity in strategic decisions, in: Studia Psychologica, 51, 4, 293-304. 
Jackson, S./ Dutton, J. (1988): Discerning threats and opportunities, in: Administrative Science Quarterly, 33, 370-387.

Jansen, R. J. G./ Curşeu, P. L./ Vermeulen, P. A. M./ Geurts, J. L. A. \& Gibcus, P. (2013). Information processing and strategic decision making in small and medium sized enterprises: The role of human and social capital in attaining decision effectiveness, in: International Small Business Journal, 31, 2,192-216.

Kostera, M. (1995): The modern crusade: Missionaries of management come to Eastern Europe, in: Management Learning, 26, 3, 331-352.

Meier, K. J./ O’Toole, L. J./ Boyne, G. A./ Walker, R. M. (2007): Strategic Management and the Performance of Public Organizations: Testing Venerable Ideas against Recent Theories, in: Journal of Public Administration Research and Theory, 17, 3, 357-378.

Mezias, S. J. (1990). The institutional model of organizational practice: Financial reporting at the Fortune 200, in: Administrative Science Quarterly, 44, 653-684.

Miller, D./ Kets de Vries, M. F. R./ Toulouse, J. M. (1982): Top executive locus of control and its relationship to strategy making, structure, and environment, in: Academy of Management Journal, 25, 237-253.

Miles, R. E./ Snow, C. C. (1978): Organizational Strategy, Structure, and Process, New York: McGraw-Hill.

Mintzberg, H./ Waters, J. (1982): Tracking strategy in an entrepreneurial firm, in: Academy of Management Journal, 25, 465-499.

Nee, V. (2005): The new institutionalisms in economics and sociology, in Smelser, N.J. \& Swedberg, R. (eds.): The handbook of economic sociology, Princeton: Princeton University Press, 49-74.

Newman, K. (2000): Organizational transformation during institutional upheaval, in: Academy of Management Review, 25, 602-619.

OECD (2005): Entrepreneurship Centre Takes Off, in: The OECD Observer, 245.

Oliver, C. (1991): Strategic responses to institutional processes, in: Academy of Management Review, 16, 145-179.

Pache, A./ Santos, F. (2010): When worlds collide: the internal dynamics of organizational responses to conflicting institutional demands, in: Academy of Management Review, $35,3,455-476$.

Peng, M. W. (2003): Institutions, institutional change and economic performance, in: Academy of Management Review, 28, 275-296.

Powell, W. W./ DiMaggio, P. J. (1991): The new institutionalism in organizational analysis. Chicago, IL: University Chicago Press.

Priester, J./ Petty, R. (1996): The gradual threshold model of ambivalence: Relating the positive and negative bases of attitudes to subject ambivalence, in: Journal of Personality and Social Psychology, 71, 431-449.

Rajagopalan, N./ Rasheed, A. M. A./ Datta, D. D. (1993): Strategic decision processes: Critical review and future processes, in: Journal of Management, 19, 2, 349-384. 
Ross, B./ Murphy, G. (1996): Category-based prediction: Influence of uncertainty and feature associations, in: Journal of Experimental Psychology: Learning, Memory and Cognition, 22, 736-753.

Scott, W.R. (2001): Institutions and Organizations, $\left(2^{\text {nd }}\right.$ ed.). Thousand Oaks, CA: Sage.

Smelser, N.J./ Swedberg, R. (2005): Introducing economic sociology, in Smelser, N.J. \& Swedberg, R. (eds.), The handbook of economic sociology. Princeton: Princeton University Press, 1-24.

Snow, C.C./ Hambrick, D.C. (1980): Measuring organizational strategies: Some theoretical and methodological problems, in: Academy of Management Review, 5, 4, 527-538.

Spicer, A./ McDermott, G./ Kogut, B. (2000): Entrepreneurship and privatization in Central Europe: The tenuous balance between destruction and creation, in: Academy of Management Review, 25, 630-649.

Staw, B. M./ Sandelands, L./ Dutton, J. E. (1981): Threat-rigidity cycles in organizational behavior. A multilevel analysis, in: Administrative Science Quarterly, 26, 4, 501-524.

Thomson, J. L. (2001): Strategic Management, $4^{\text {th }}$ ed. London: Thomson-Learning.

Townsend, D. M./ Hart, T. A. (2008): Perceived Institutional Ambiguity and the Choice of Organizational Form in Social Entrepreneurial Ventures, in Entrepreneurship: Theory and Practice, Baylor University, 685-700.

Weick, K. E. (1979): The Social Psychology of Organizing, $2^{\text {nd }}$ ed. Reading, MA: MIT Press.

Yuan, K.H./ Bentler, P.M. (2004): On chi-square difference and z-tests in mean and covariance structure analysis when the base model is misspecified, in: Educational and Psychological Measurement, 64, 737-757. 